干潟実験施設による底泥系メソコズム実験

Benthic Mesocosm Experiments by Tidal-Flat Experiment Facility in PHRI

細川恭史* 桑江朝比呂*

Yasushi HOSOKAWA Tomohiro KUWAE

\begin{abstract}
Mesocosm experiment facility for coastal tidal flats was constructed in the laboratory of Port \& Harbour Research Institute, Ministry of Transport. This facility has three tidal flats, surface area of which is $15-20 \mathrm{~m} 2$ each. Dry sediment was transported from natural tidal flat in tokyo Bay. Sediment was placed in the facility with $50 \mathrm{~cm}$ thick. Natural untreated seawater was introduced to the facility to be given semi-diurnal tidal fluctuation of $70 \mathrm{~cm}$ in 11 hours. Operation started from Jan., 1995. Initially, no benthic biota was found. No transplantation nor input of benthic animals were made by human hands at all. Two years' monitoring shows that within 8 months initial intrusion of benthic biota was finished. After that, succession of benthic pieces started.
\end{abstract}

KEYWORDS : Benthic Ecosystem, Mesocosm Experiments, Coastal Tidal Flat, Nutrient Budget, Successions

1.はじめに

自然界においては、生物は周辺環境や周囲の生物との相互作用（つまり生態系）の中で生活している。生 物作用を介して起こる種々の機能の解明には、生物個体の働きに関する研究に加えて、相互作用の中での働 きに関する知見が必要になる。

自然の様子そのものを自然界の中で観察することは、自然科学の基本であるが、自然界の機能は作用因子 ・影響要因が多くこれらを制御することができず、機能解析上なかなか思うようなデータが得られない。一 方、フラスコ内に閉じ込められた微細な生物などの比較的均質な生物相の工学的な扱いは、発酵工学や薬学 などとして長い歴史を持っている。培養条件を制御することで機能変化等の応答性を見ることができる。し かし、少し大きな生物も含んだ多様な生物相の様子を探る実験手法や挙動解析については、未確立の部分が 多い。近年、個体もしくは個体群観察と、自然界の観察との中間に、やや大きな実験系による観察が試みら れている。自然界の複雑な生物相互作用をある程度組み込み、人為的な操作性を保持した実験系は、メソコ スム実験装置 ${ }^{1}$ などとも呼ばれている。生態系の自立的な運動が一定程度保証され、そこに生起する特定の 相互関係がより詳しく観察できるという利点がある。ここでは、沿岸干潟生態系の観察のために、底泥を含 んだ実験系を新規に作った例を報告したい。

\title{
2. 干潟の保全と生態系
}

沿岸の干潟とは、潮汐による海水面の上下に伴い干出と水没を繰り返す比較的平坦な砂泥の場所とされて いる。大気・海水・土壤の出会う場所である。このため、水深・水分・流動・温度・酸素の豊富さ等に関し さまざまな環境条件の場所が見いだされる。また、陸上からの影響や負荷を最初に受けとめる場でもある。

* 運輸省港湾技術研究所 海洋環境部 Port \& Harbour Research Institute (PHRI), Ministry of Transport 
各種の生物が、自己の生存に適した場所を見つけられるこ上もあり、多様な生物が高い生産性を持って生息 している場所でもある。干潟泥面では、水没時に海水に含まれている物質との交換が行われ、干出時に大気 との交換が行われる。干潟生物群集の構成者には二種類有り、ひとつは干潟に定住している底生生物（バン トス）であり、もう一つは外部境界から周期的に訪れる来遊者である2。千潟に出かけて泥をすくい採って みると、目につく底生動物は、アサリやシオフキなどの二枚貝・ゴカイやシャコなどの多毛類・ウミニナな ぞの腹足類・エビなどの甲殼類である。多くの干潟では、これらの動物は生息生物重量で卓越している。

干潟はその位置や生物相の特徵から、環境上色々な役割を担っている。(1)採貝やノリ採取等の漁獲の場、 沖合い魚の産卵や成長の場といった生物資源提供に関連した役割、(2)水鳥の生息や渡り鳥の飛来場、沿岸希 少種の保全も含めた沿岸生態系の育成場といった自然保護の役割、(3)潮干狩りの場、バードウォッチングの 場、生物生態系の学習の場といった利便やアメニティの提供の役割、(4)都市からの水質污濁負荷の生物同化 の場といった環境浄化の役割などがある。一方、陸に接した浅い水域であることから容易に陸地化でき、ま とまった土地の供給場としても昔から活用されてきた。

現実には、沿岸の開発にともなって干潟が失われたり、陸域からの過度な污濁負荷や沿岸環境の悪化等に より干潟の役割機能が劣化することもある。そこで、適切な管理によって役割を振興させたり、劣化した干 潟を修復したり、あるいは新たに干潟を造成し干潟の機能を発現させようという要請が出てくることがある。 多くの場合、こうした要請汭湾奥の都市近郊干潟であり、水質浄化機能やアメニティ機能（水鳥の飛来や 潮干狩り）の改善が求められてくる3）。水質浄化や水鳥飛来のためには浄化に関与寸る生物や水鳥の餌とな る生物の生息が重要となる。有機物の摂取の大きさや水鳥の食性などから、キーとなる生物は、多くの場合、 数 $\mathrm{mm}$ 数 $\mathrm{cm}$ の大きさを持つマクロベントス、もしくはそれ以下の小生物であると思われる。

有機物（餌）の流れから見る之、自然生態系は、「生産者」「消費者」「分解者」から構成されている。 光合成により、無機栄養塩などから有機物を作り出寸植物を「生産者」と呼ぶ。食物連鎖により、この有機 物などを摂取する動物を「消費者」と呼ぶ。有機物片を分解し無機化するバクテリアなどを「分解者」と呼 ぶ。これら三者により、栄養塩の合成・利用・分解の循環が行われることになる。干潟では、「生産者」は、 主に底泥表面の付着藻である。「消費者」は、底泥のベントスや、さらにこれら動物を捸取する魚や水鳥で ある。「分解者」は、海水中や底泥中のバクテリアである。また、底泥では好気的環境と還元的環境が深さ 方向に接して存在することから、土壤中のバクテリアによる大きな脱窒作用が期待されている。こうして、 栄養塩は干潟生態系内を循環し、干潟での栄養塩の貯留や浄化作用が発現されることになる。

潮干狩りができるためにはアサリが生息することが、水鳥の飛来には餌となるゴカイや二枚貝の生息が必 要である。アサリやゴカイの生息も、干潟の物質循環に支えられている。

\section{3. 千潟の研究課題と実験手法}

では、浄化の機能が高く、アサリが採取できたり水鳥が飛来してくれる干潟はどう作ればいいのだろうか。 どのような地形や生物活動が大切だろうか。周辺の条件が少し変化したら、浄化の機能はよ゙う変わるのだろ うか。海水と干潟泥との接触のさせ方や干潟泥の素材や地形など、土木的な必要情報を得ておく必要がある。 その際、広い干潟現地での調査では、潮の上げ下げの水量評価が大変な上に河川水や地下水の混入が排除で きず、また、長期の連続した観察も困難である。周辺条件の変化を作り出し、その応答性を測定するこ上も、 現地ではやりにくい。そこで、境界がはっきりし、条件操作が容易な模型実験の活用を検討した。

植物の培養実験と、動物の培養実験とを別々に行っても、両者の共存時の植物の食べられ方や住み分け具 合は推測できない" ${ }^{4}$ 。生態系の様子は、多くの関連生物が一緒におりそれらが自然にふるまえる状況下での 観察が望ましい。自然なふるまいを重視する上、生物の持つ時間や身体の大きさを短縮することはできない。 つまり、縮尺 1 の歪みなしの模型が望ましい。金魚と金魚鉢の大きさを想起すれば解るが、生物作用を含ん 
だ模型については、対象生物の大きさやその活動範囲を考慮しある程度以上の大きさが必要とされる。さら に、生物同士や環境条件との相互作用（つまり生態系）を模型上に生起させ上うとする場合には、単一種の 培養とは異なり、相互の作用に見合ら広さやなじませる時間が必要になる。つまり、装置内に生物系のダイ ナミズムを含む小宇宙 (コスム) を現出させることに他ならない。沿岸浮遊系り生物を含んだ実験について は、現場での水塊囲い込み実験 ${ }^{5}$ や屋内装置での実験のなよ゙いくつかの事例がある。装置の大きさによって、 ミクロコスム：メソコスム・マクロコスムなどに分類されている。それぞれの大きさと、特徴や対象となる

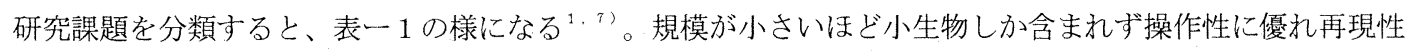
が良いが、規模が大きくなるにつれより現場の条件に近くなり長期的な様態や系内の部分的な分布特徴など の観測に向いてくる。10〜 $100 \mathrm{~m}^{3}$ のオーダーの水容積規模になると、メソコスムと呼んでいるようである。 流動による均質化がない沿岸底泥系でも、類似の分類が可能である。底泥系では、場の生息生物が保持し ている栄養塩量以上の大量の栄養塩が底泥粒子に含まれていること、微細底泥が吸脱着能を有していること など、底泥の存在自身による影響がある。底泥の影響は、おおむむ祲激な変動の緩衝や微小スケールでの 環境の多様性をもたらし、逆に、環境条件の急激な変化操作や場の均質性をそこなう力向に働く。したがっ て、浮遊系よりもやや小さな空間スケールでも、メソコスム的・マクロコスム的な性格になりやすい。この 表では、底泥面積が $1 \sim 10 \mathrm{~m}^{2}$ のオーダーある模型をメソコスム、それ以下をミクロコスムと分けている。 底泥系でも、自然の一部の囲い込み型のメソコスム ${ }^{8)}$ と新規に創出させる装置型のメソコスムとが考えられ る。いずれにしても、実験の目的に応じた大きさと環境条件の設定・管理が肝要になってくる。

ここでは、干潟の機能解析のために、二枚貝・多毛類などのベントスまでを含む底泥系装置が必要とされ る。体長数 $\mathrm{mm}$ 以上のベントス（マクロベントス）が生物群として生息し、これを支える生産者・分解者 が共存し、ベントス等が自然にふるまえる環境条件が与えられることが装置の持つべき条件である。このた め、なるべく大きな干潟装置が望ましいことになる。

さて、二枚貝や多毛類は、産卵期・浮遊期・定着期を経て底泥などに定着成長し、やがて成体になる。生 物種にもよるが、 1 年以上の寿命を持っている。付着藻も、生息量には季節変動がありそうである。干潟生 物の時間スケールに対し、潮汐の時間スケールは小さい。干潟生物の季節変動を装置内で起こさせるために は、季節変動に対応した空間が必要である。浮遊卵や浮遊幼生の浮遊距離についての知識はないが、内湾規 模の空間である可能性がある。一方、短期間の実験を行うためにのみ装置を用いることにして、季節変動を 実験の初期条件として装置内に人為的に与えるためには、浮遊幼生・定着初期の幼生・成体など各段階の個 体を別の場所で確保しなければならない。こうした難しさを避けるため、底泥系のメソコスムは、普通、一 部開放系にしている。つまり、内湾規模の大きな変動を自然に任せ、実験装置が自然と接触し交流する部分 を設けている。自然の海水の導入による装置内の海水の交換などである。一部開放系の装置では、接してい る自然と同じ時間が装 置内にも流れているこ とになる。冬に夏の実 表一1 実験装置の規模とそれに忘じた特徵・適した研究課題の分類 (高橋正征を改変)

験は出来ないことにな る。

それでは、この実験 装置内では、自然と同 一の生態系が形成され るのだろうか。あるい は、実験に都合の良い ような任意の生態系が うまく装置内に作孔る

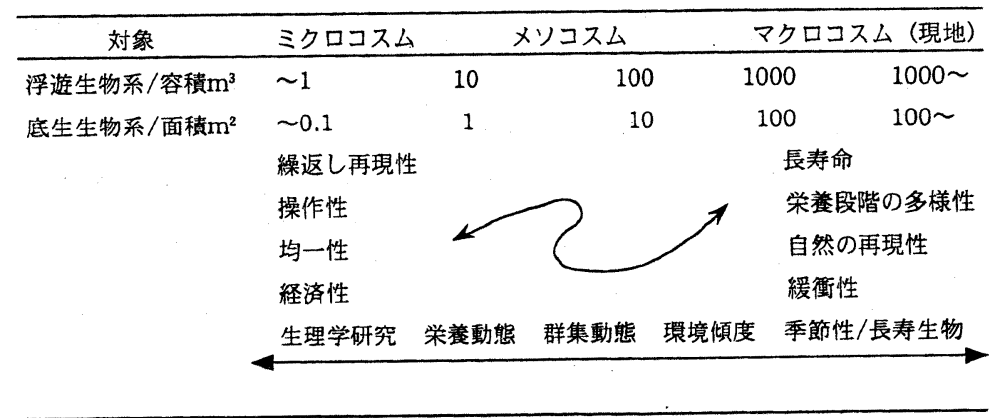


のだろうか。干潟の生態系の構造自体が十分には解明されていないので不明である。どうすれば、自然と似 た系が出来るかは解らない。フラスコやビーカーなどの小さいスケールの容器で、複数の生物種を混在させ る浮遊系の実験では、栄養の条件や共存生物の条件によってかなり異なった系が形成されることがあるよう である。「自然は、その条件に最も適した系を作る。」という概念は、生態学の基本的な態度の中にもある ようである。ここでは、一部開放系の装置であることから「自然の自己デザイン」゙に任せるべき点がある ことを認め、装置内り生態系が自然上は少し違うことを前提に実験しようとした。マクロベントスまで含ん だ生態系が装置内にどう構成されるか不明なので、当初は、人為的な生物の移植は一切行わず、自然海水に 含まれる生物や幼生がひとりでに加入し定着寸るに任せることにした。自然干潟とまったく同じではないが、 かなり似ている系がひとりでに出来ることを期待している。自然干潟類似の系が生み出されるためには、類 似の規模と環境を持ち、類似の相互作用が生起していなければならない。装置の規模が小さいと、一部開放 系に起因して持ち込まれた自然界の擾乱が、装置内で致命的な影響となる恐れがある。

自然加入による系の形成を決意すると、生態系の応答や機能の比較実験では、インパクトの無い系との相 互比較という手法を採る必要が出てくる。対照系としてインパクトを与えない系を横に作るか、もしくは、 インパクトの無い時期の系であらかじめ測定しておくという手続きが必要になる。前者の場合、複数の水槽 の同時運転が必要であるし、後者の場合、インパクトや応答が短時間である現象しか扱えない。また、自然 干潟での生態系の観察上、装置生態系上の比較も重要である。

装置で得られた知見が現実の干潟づくりによ゙う役立てられるのかは、現地と装置内との生態系の構造・機 構の差の理解なしには、考えられない。土木設計のための物理機構に関する実験でも、作用力や応答系は単 純化していることが多い。装置内の系が自然とまったく同じでなければ意味がないとはいえない。

この実験装置では、どんな実験が可能なのであろうか。(1). 現地調查ではなかなか解明できない干潟をめ ぐる物質収支の観測が可能である。干出時に大気と触れ・巻き貝が泥表面を動き回り、水没時には海水と触 れ・付着藻が光合成をし・二枚貝が懸濁物を取り込み・ゴカイが巣穴を掘る、上いう状況での栄養塩や有機 物のやり取りの観測が可能である。上げ潮・下げ潮の給排水路から採水できれば、一潮汐間での水質の変化 が観測でき、干潟の単位面積あたりの活性などとして解析できることになる。(2). 実験装置の環境条件が操 作できれば、環境条件の大きな変動に対する生態系の応答が観察できる。赤潮・青潮や流出油が押し寄せた とき、干潟で何が起こりそうかの実験ができる。あるいは、冷たい夏での様子、台風で流出したシルトが干 潟を覆ってしまったときの様子、なども温度制御装置や素材が整えば可能であろう。こうした極端な環境条 件は現地ではなかなか作り出せない。さらに、(3). 特定のベントスを加えたり除去したりしたときの生態系 の変動の様子も見れるだろう。例えば、ある種の浄化能力の高い動物を高密度で生息させることが、干潟の 健全な生態系を崩すことはないのか、といった課題の実験的検討は今まではなかなかできなかった。

\section{4. 干潟実験施設の計画}

\section{1 予備実験}

実験施設の計画に先立ち小規模な培養実験を行った゚?。縌 $1.2 \mathrm{~m}$ 横 $0.8 \mathrm{~m}$ の上面開放のプラスチック容器 に混合干潟泥を入れ、研究所前面の久里浜湾海水を掛け流した。海水は無処理のまま容器に導き、干潟泥面 上を一端から多端へと流した。水位は一定で $10 \mathrm{~cm}$ 程度とした。導水時の海水の滞留時間は概ね数分程度で あり、新鮮な海水とよく交換されていた。一日 2 回合計 6 時間海水の導水を停止し、干出状況を作り出した。 東京湾盤州干潟で採取したマ叭ベン双等を類似密度に移植し、生息生物量の変化を追跡した。また無移植つ容 器も並べて運転した。観察は平成 5 年 9 月から始まり、装置の手直しをしつつ平成 6 年 12 月まで続けた

その結果、付着藻のクロロフィル濃度はほぼ現地干潟並汇維持できたほか、ゴカイ・二枚貝・巻き貝・カ

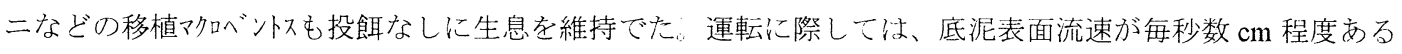
ことが望ましいこと、生息場所の異なるマクロベントス緒に培養寸るためには容器内に起伏を設ける上良いこ 
と等が解った。容器内ではクロロフィルに対し分解途上のフェオ色素の比が高くなりがちであり、分解産物 の蓄積傾向が認められた。装置内泥面が限られていたため枠取り採取による定量的な検討は不十分であった。

\section{2 干潟実験装置の計画}

(1) 干潟サイズの検討

干潟実験装置の必要泥面積を考えてみる。代表的マクロベントスで比較的大きな個体を考える。例えば、 アサリの個体数密度は季節や地盤高により変動し、東京湾岸盤洲干潟では $10 \sim 3000$ 個体 $/ \mathrm{m}^{2}$ 程度である。 また、巻き貝のウミニナで、アサリの半分から倍程度の生息密度である。個体がたまたま混入したという状 況でなく、個体群として挙動をするための必要な最少個体数は不明である。統計的解析には $30 \sim 50$ 個体程 度は欲しい所から類推して、盤洲と類似の生息を示すならアサリの場合には最低数 $\mathrm{m}^{2}$ 以上、ウミニナの場 合には $10 \mathrm{~m}^{2}$ 程度の面積が必要ということになる。

干潟のベント腚量には、通常 $50 \mathrm{~cm}$ 角の枠を用い枠内の底泥を一定深さまですべて掘り起こし、一定の 目合いのふるいでふるい分けする採取法をとっている。この枠の大きさの妥当性の検討は別途必要であるが、 現地での従来の採取法との比較のためには採取のサイズを揃えておきたい。また、底泥質や微生物分析には 別途コア試料の採取が必要になる。従って、1回の分析で、 $0.3 \sim 0.5 \mathrm{~m}$ 程度の面積を乱すことになる。一 方、底泥採取行為が、施設内の生物相に対し大きな擾乱となっては困る。浮遊プランクトンの培養法などか ら類推して、採取面積が全底泥面積の数\%程度なら我慢できると考えた。ただし、はじめの採取の影響が無 くなる程十分に時間をあけてから次の採取が行われるとした。ベントスの分布が均一とすれば、一力所の採 取でその時点の状況が把握できる。すると、干潟泥の面積としては $10 \sim 50 \mathrm{~m}{ }^{2}$ 程度欲しいことになる。

泥深さは、対象ベントスによる。ここでは、実験の主目的から、二枚貝としてはアサリ・多毛類としては ゴカイ・巻き貝としてはウミニナといった体長数 $\mathrm{cm}$ 程度の表在性もしくは体長の数倍程度の穴を掘る生物 を対象にすればほぼ良い。こうしたベントスが底泥下部の境界を検知しないですむ程度の深さを確保したい。

\section{（2）装置の制御環境条件の検討}

実験装置内のベントスが自然干潟に自身が居ると思い込ませるためには、自然の条件に似た環境条件を設 定する必要がある。潮の干満による干潟泥の定期的な水没干出は、干潟であるための基本条件である。潮汐 振幅に関しては、最大の能力として太平洋岸での大潮程度はおこしたい。潮汐の周期に対しては、日潮不等 （毎日異なった潮汐が大潮や小潮として起きること）が望ましいが、当面半日周期の潮でも良いとした。

その他の条件に関しては、研究の主目的から、底質と水理条件との制御を中心に考えている。底質は、異 なる底質を運び込んだり地形を整形することにより変化できる必要がある。いくつかの区切りを設け、異な る底質や地形が同じ環境条件に晒される様にしたい。予備実験から水理条件が大切であると想定された。干 潟の泥表面近くで梯々の擾乱が観察される。ここでは、泥表面に波か流れを与えられるように考えた。

水質に関しては、極端な条件（例えば無酸素条件）での干潟生態系の反応を研究の目的に加えたいので、 水質調整槽が必要である。ただし、当面、干潟装置による実験の経験を積むまでは、水質は日毎の変動や季 節変化を含め研究所前面の久里浜湾海水を処理しないで用いることを基本と寸る。従って、海水の汲み上げ 装置と配水系が必要である。装置に用いた海水は再び久里浜湾八と戻すことになる。このため、装置は完全 閉鎖系での運転（同じ海水を貯留槽と干潟装置との間で行き来させることで干満を作り出す運転方法）上一 部開放半閉鎖系での運転（引き潮のとき一部もしくは全部の古い海水を湾に捨て、満ち潮の海水として新し い新鮮な海水を汲み上げて用いる運転方法）との両方の運転が可能としたい。

日照は、泥面付着藻の活動や泥温等に大きく関与する。この制御には、大型の照明装置が必要である。こ こでは、天空からの太陽の日射をそのまま利用することにし、人為的な制御をしないことにした。これは、 外界の季節変動や天気の日変動を装置の境界条件として取り込むことを意味している。 
気温は、干潟泥の熱環境にゆるい影響を与える。気温の制御のためには、断熱構造の建屋を設け、冷暖房 装置を備える必要がある。日照の制御をしない以上、気温の制御のみをする意味は薄い。ただし、干潟特有 の海陸風については、干潟泥の水分蒸発などに効くと思われるが生態影響などが不明であったため、その必 要性は判断できなかった。大型のファンの設置により風がおこせるが、とりあえず設置していない。

水温は、様々の生物活動や活性左右寸る。沖合水の水温変動・海水表面での太陽熱の吸収や大気との熱 交換・浅海泥面での熱交換等の機構により変化する。制御には、水槽内もしくは流入海水に対する加熱泠却 装置が必要であり、水量が大きいことから大きなエネルギ一を必要とする。ここでは、自然海水を利用卞る こと、泥表面の加熱が直達太陽光に上り起きること、気温を制御しないこと等から、制御しないことにした。

降雨は、海水の塩分濃度や水温に影響を与える。降雨によってのみ特殊な微量栄養分等が大気から持ち込 まれることも考えられる。使用海水が河川の流入を引き受けた湾の水であり、海水を経由して降雨の影響が 取り込まれることから、降雨は無視し、実験管理の都合から装置には屋根を設けることにした。

実際の干潟では、河川経由の影響も含め年に数回程度の台風の効果等があり、なぎ倒されたアシの茎等が 漂着し翌年以降の干潟生物活動に影響を与えることも考えられる。こうした低頻度の事象による長期的なス ケールでの効果を、イベントに依存する効果と名付けている。どんな装置でも、装置が自然界から隔離され たとたん、多かれ少なかれイベントに依存する効果は自然とは違ってくる。隔離実験装置の宿命である。非 常に長期の実験では、こうした効果の影響が徐々に大きくなり、自然系とはかなり様子が違ってくることも ありうる。このため、実験の時間スケールに注意しつつ、東京湾岸の類似の干潟での現地調査を併用し、現 地と実験施設との相互比較をしながら検討を進めることにした。

\section{5. 施設の概要}

5. 1 施設の様子

施設上屋注、縦横 $18 \mathrm{~m} \times 21 \mathrm{~m}$ の鉄 骨スレート壁で南面全面と西面・屋 根の大部分がガラス張りになってい る。実験装置はF R P 製の干潟水槽 と貯留水槽・調整水槽、ポンプ類、 潮汐発生装置等から成っている。干 潟水槽は、 $8 \mathrm{~m} \times 9 \mathrm{~m}$ の矩形で深さは $1.7 \mathrm{~m}$ ある。現在は、図一 1 に示すよ うに、干潟水槽を 3 分割し、 $8 \mathrm{~m} \times$ $3 \mathrm{~m}$ の矩形が 3 つ並んだ状態で使用し

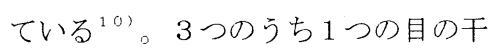
潟実験水槽では、冠水時に波がおこ

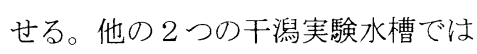
水槽内循環流がおこせる。干潟泥面 は波のおこせる水槽で約 $15 \mathrm{~m}{ }^{2}$ 、他 の水槽で $24 \mathrm{~m}{ }^{2}$ の面積がある。 3 水 槽それぞれに潮汐発生装置が備えて ある。潮汐発生装置の背後に 3 つの 貯留水槽が女る。久里浜湾海水はい ったんここに貯留され、上げ潮時に は貯留水槽から潮汐発生装置に海水が供給される。下げ潮時には潮汐発生装置から貯留水槽に返送されるか、

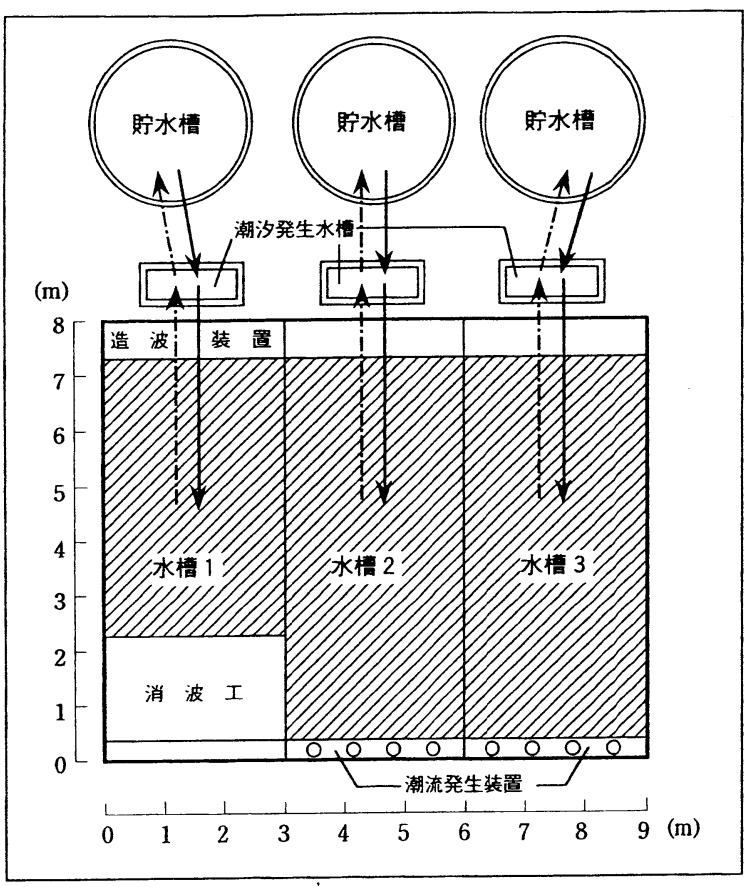

図-1 実験水槽配置平面図 ${ }^{10)}$ 及び海水のフロー (実線：上げ潮、破線：下げ潮） 
久里浜湾に返される。

干潟泥は、東京湾岸の盤洲干潟 より搬入した。水槽の最下部には 通水用の空間を設け、その上に海 砂を敷いた。淩渫後陸上に数力月 間仮置きされていた乾燥泥を、海 砂上に $50 \mathrm{~cm}$ 厚で平らに敷き均し

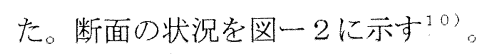

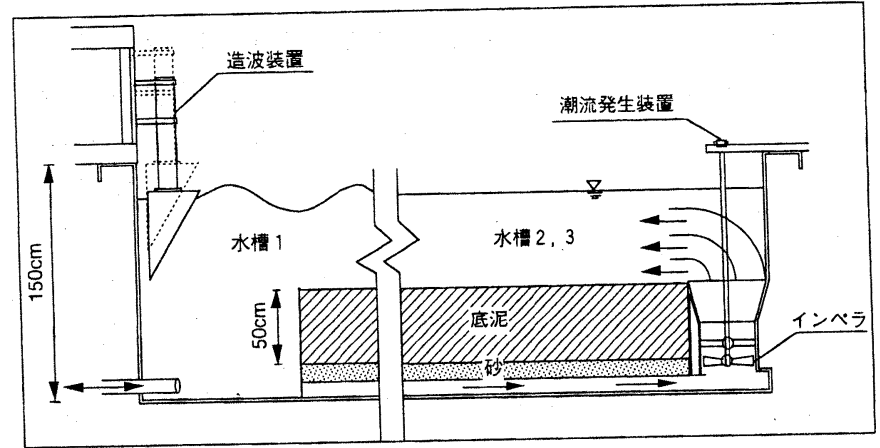

図一 2 実験水槽断面図 ${ }^{10}$

\section{2 運転の様子}

平成 6 年 12 月より運転を開始した。当初は装置能力や運転手順の確認を行った。平成 7 年 1 月より本格 的な連続運転を始めた。潮汐は振幅 $50 \mathrm{~cm}$ のノコギリ波を約 10.5 時間の周期で与えた。満潮面は底泥表面上 $20 \mathrm{~cm}$ にある。波は、1.5 秒周期のものを満潮時に波高 $8 \mathrm{~cm}$ となるように与えた。流れは、満潮時表面流速 が $7 \mathrm{~cm} / \mathrm{s}$ 程度になるように与えた。海水は、お打む祇週に 3 回久里浜湾内水と交換した。流れをおこした 1 つの水槽だけは、 1 年後から週 1 回の交換とした。毎日、水温・泥温・塩分等を測定した。底泥表面に働く せん断力を評価すると、表一2の様になった ${ }^{12)}$ 。水槽 1 では水没時に底泥の移動が起こっている。

\section{3 生物生息の様子}

本格運転開始後、 2 及び 3 力月 後に底泥中のバクテリアの様子を 調べた。搬入もとの盤洲干潟での 同じ時期の観測值と比較しても、 菌体数密度・酸素消費速度・分解 活性等ほぼ類似のものであった。
表一 2 底泥表面に働く摩擦速度・ せん断力 ${ }^{12}$ （）内は平均值。

\begin{tabular}{lcc}
\hline & $\begin{array}{c}\text { Friction velocity }\left(U_{*}\right) \\
\left(\mathrm{cm} \mathrm{s}^{-1}\right)\end{array}$ & $\begin{array}{c}\text { Shear stress }\left(\tau_{0}\right) \\
\left(\times 10^{-5} \mathrm{~Pa}\right)\end{array}$ \\
\hline Pool 1 & $8.6-10.0(9.1)$ & $751-1028(852)$ \\
Pool 2 & $0.26-0.65(0.45)$ & $0.69-4.86(2.45)$ \\
Pool 3 & $0.26-0.82(0.58)$ & $2.55-9.80(6.51)$ \\
\hline
\end{tabular}

その後、糸状のメイオベントスが

確認され、泥表面に付着藻が定着し始め表在性巻き貝等が観察された。藻の定着が始まった 6 月と定着が進 んだ 7 月に、栄盖塩類等について、上げ潮時の流入フラックスと下げ潮時の流出フラックスを観測した。秋 頃から、流れをおこす水槽にシオクサの固着が見られた。1 年経過後にはアサリやゴカイが加入していた。

\section{6. 今までに解ってきたこと}

従来の実験に比べ規模の大きい装置とはいえ、実際の干潟に比べると狭い。こうした空間的な制約があっ ても、それなりの生物相が自然に形成された。増殖時間の短い微小生物は、かなり早期に加入してくる。バ クテリアからマクロベントスまでの個体数密度を盤洲干潟と比較すると、図一 3 の様になる ${ }^{13)}$ 。小さな生 物ほど生息個体数が大きいという分布は似ている。生息個体数密度は、分解者>生産者>消費者の順に小さ くなり、ある種のピラミッド構造をなしている。ただし、マクロベントス相を中心に、生息生物種は盤洲干 潟とは少しずつ異なる。実験施設内ではマクロベントスで少なめ、付着藻で多めの傾向も見受けられる。

6 月・ 7 月の栄養塩の収支フラックスを表一 3 に示す $^{10)}$ 。無機態のリン（ＩＰ）や窒素（ＩＮ） は海水 から除かれて干潟泥へと移動している。6 月に比べ 7 月での栄養塩除去が大きい。水温や日照の条件や流入 栄養塩濃度の差もあり、7月のほうが付着藻の栄養塩の取り込みと利用が大きかったせいだと思われる。生 物の活性が海水と干潟泥との物質（特に栄養塩）のやり取りに大きく影響することが解る。加叫、 、゙表し

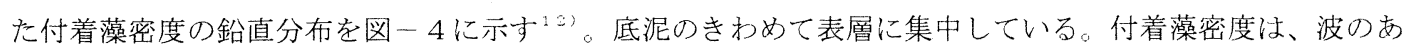


る水槽で低めであった。底泥の擋乱移動の物理的影響を受けているものと思われる。底泥表面のバクテリア の細胞密度は、図一 5 のように付着藻の量上ほぼ直線的な関係があることが分かった ${ }^{12)}$ 。付着藻の生息密 度を介して、表層バクテリアの細胞密度も底泥摚乱の影響を受けているようだ。

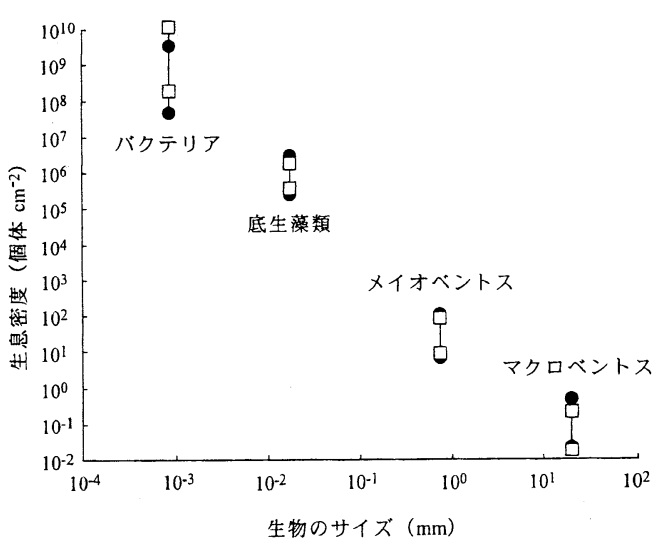

図一 3 生物のサイズごとの生息個体数密度 ${ }^{13)}$

(: 盤洲干潟の值 '93.12-'95.10, $\square$ : 実験施設の值 '95.9-12)

個体数密度で見たマクロベントスの種構成の変遷を

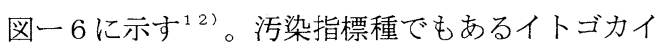

(Capitella sp. ) が海水交換を抑えた水槽 3 で大きな 構成比を占めている。また、いずれの水槽でもホト卜 ギスガイ (Musculisla senhousia) や Capitella sp. 等の いわゆる日和見種が優占している。初期の遷移状態に あると思われるが、今後大型で媣い巣穴を形成する種 に変わってゆくのか、それとも日和見種のみが卓越し たままになるのが、さらに継続した観察を待たなけ ればならない。囲い過ぎた干潟では閉鎖性が強まり、
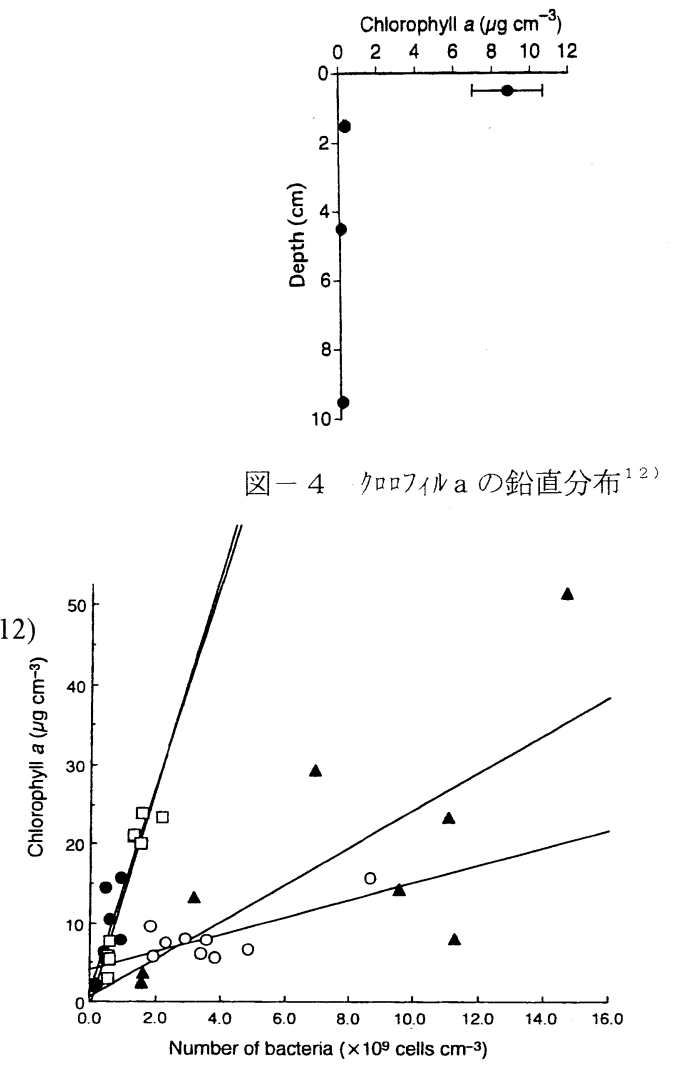

図一 5 バ行アの細胞密度と吅フィルa との関係 ${ }^{12)}$

(O :'95.7,

'96.3,

:'96.7,

A :'96.9)
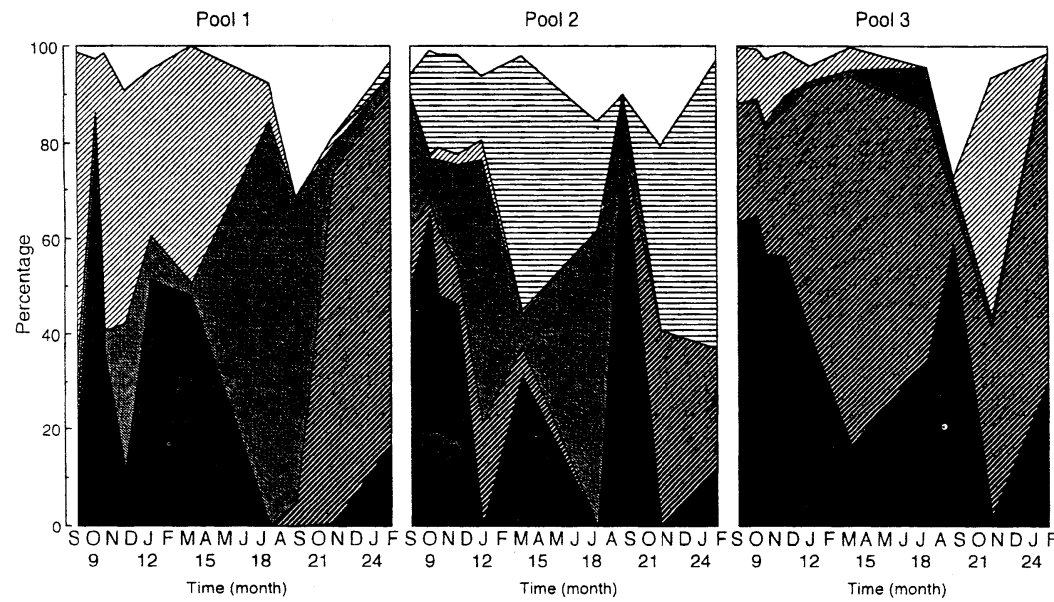

$\square:$ Others.

目: Corophium sp.;

$\mathbb{Z}$ : Ceratonereis erythraeensis;

: Musculista senhousia;

: Capitella sp.;

1: Haloa japonica;

図ー6 個体数で見たマクロベントスの種構成の時間変化 


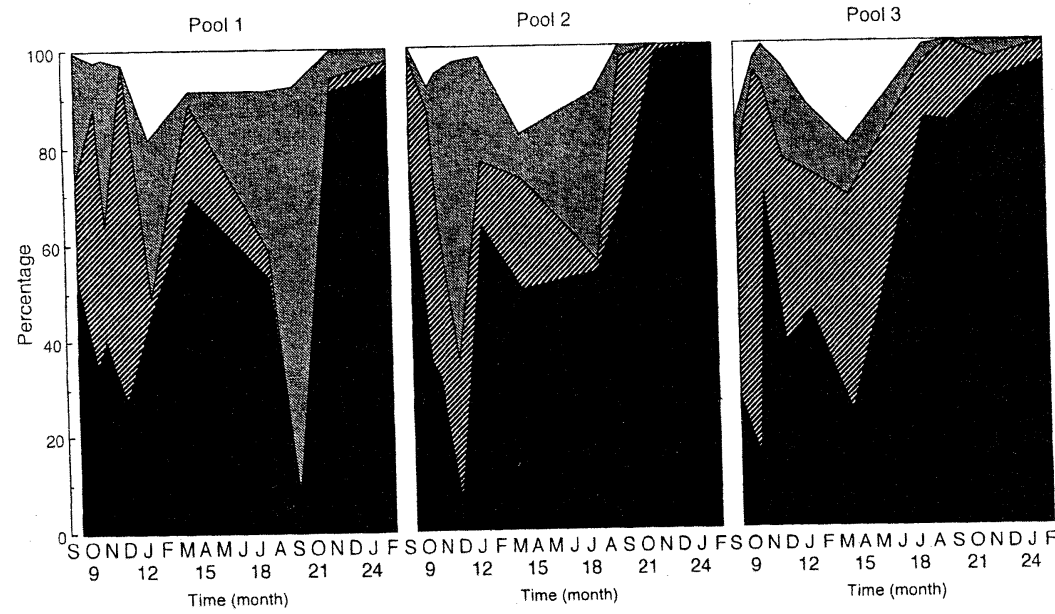

$\square$ : Others

: Harpacticoida:

$\mathbb{Z}$ : Oligochaeta;

: Nematoda;

図一7 個体数で見たメイオバントスの種構成の時間変化 ${ }^{12}$

閉鎖性に特有な生物種が増え

てくる可能性がある。メイオ ベントスの種構成の変化を図 - 7 に示寸 $^{12)}$ 。線虫類

（Nematoda）や貧毛類

(Oligochaeta) 等が優占し

ている。生息密度も構成比も 水槽間の有意な差は検出でき なかったが、11 カ月後から
表一 $3 \quad 6 \cdot 7$ 月の干潟の 1 日・ $1 \mathrm{~m}^{2}$ あたりの物質収支 ${ }^{10)}$

(単位 : $\mathrm{mg} \mathrm{m}^{-2}$ day $^{-1}$ )

\begin{tabular}{|c|c|c|c|c|c|c|c|c|c|}
\hline 場所 & 季節 & 時間 & OP & IP & ON & IN & $\mathrm{NH}_{4} \cdot \mathrm{N}$ & $\mathrm{NO}_{2}-\mathrm{N}$ & $\mathrm{NO}_{3}-\mathrm{N}$ \\
\hline \multirow[t]{2}{*}{ 干潟実験施設 } & 6月 & 夜間 & -0.5 & -0.3 & 6.1 & 0.1 & 2.6 & -0.5 & -2.0 \\
\hline & 7月 & 昼間 & -4.3 & -4.3 & 13.6 & -250.6 & -114.4 & -17.9 & -118.3 \\
\hline
\end{tabular}

$+:$ 海水中の物質が増加, 一: 海水中の物質が減少。

流量・物質濃度は、1潮汐の間について1-2時間ごとに実測。

22 カ月後を境に優占種が貧毛類から線虫類へとシフトしていた。

\section{7. 今後の課題}

干潟をめぐる物質の収支の知識が蓄積されてきた。卓越素過程を測定するとともに、干潟全体のフラック スも計測し、物質循環の理解を墚めることが今後必要である。干潟メソコスム実験の方法論や活用法につき、 現地干潟との対比の中で考えて行きたい。本装置に関し、東北大学栗原 康名誉教授には親切なご指導を受 けた。本報告は、下記参考文献 13)をもとに、その後の解析結果を加えるなどして作成した。

\section{参考文献}

1) 西条八束・坂本 充 :メソコスム湖沼生態系の解析、名古屋大学出版会、(1993)

2) 玉井恭一：藻場と干潟、岡市友利ら編「瀬戸内海の生物資源と環境」恒星社厚生閣の第 2 章第 5 節、pp.75-79、(1996)

3）港湾環境创造研究会：よみがえる海辺一環境創造 21 一、山海堂、231p.(1997)

4 ) 栗原 康 : 有限の生態学、同時代ライブラリー 194、岩波書店、209p.、(1994)

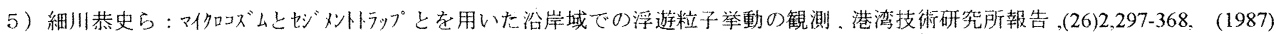

6) Kangas,P. \& W.Adey:Mesocosms and ecological engineering, Ecological Engineering,(6)1-3, pp.1-6,(1996)

7) Odum,H.T.:Scales of ecological engineering, Ecological Engineering,(6)1-3, pp.7-20,(1996)

8) M. F.Moffett(Ed.) :Effects,Persistence and Distribution of Diflubenzeuron in Littoral Enclosures, U.S.EPAMid-Continent Ecology Division, Duluth , Final Report:2898, 501p., 1995

9 ) 小笹博昭ら：人工干潟の室内実験、生態系工学第 14 回シンポジウム講演要旨、生態系工学研究会、pp.16-33、(1994)

10 ）細川恭史ら：干潟実験装置を用いた物質収支観測、港湾技研資料 No.832、22p.(1996)

11 ）桑江朝比呂・細川恭史：干潟実験施設での物質収支実験、ヘドロNo.67、pp.33-38、（1996)

12 ) 桑江朝比呂ら：干潟実験施設にお忊る底生生物群集の動態, 港湾技術研究所報告 (37)2、(1997) (印刷中)

13 ）細川恭史・桑江朝比呂：干潟案験施設によるメソコスム実験、土木学会誌 (82) 8、pp.12-14、 (1997) 